\title{
Effectiveness of Health and Nutritional Education Intervention to Combat Anemia Problem among Adolescent Girls
}

\author{
T. Kamalaja*, M. Prashanthi and K. Rajeswari \\ Foods \& Nutrition, AICRP-H.Sc, Professor Jayashankar Telangana State Agricultural \\ University, Rajendranagar, Hyderabad-30, Telangana State, India \\ *Corresponding author
}

\begin{abstract}
A B S T R A C T
\end{abstract}
Anemia is the major nutritional problem observed in girls during adolescence, affecting growth and development and increasing their vulnerability to unproductive. Adolescence is the crucial time for improving their attitude levels towards good nutritional practices and

\section{Key words}

Health, Nutritional

Education, Anemia,

Adolescents

Article Info

Accepted:

20 August 2018

Available Online:

10 September 2018 knowledge levels. The present study is a Community based intervention study conducted with adolescents (150 control and 150 experimental) aged 13-17 years, through health and nutrition education intervention for a period of 4 months on KAP scores and hemoglobin level status. Primary data on KAP scores and hemoglobin level status was collected before and after intervention and statistically analyzed. The overall findings revealed that Nutrition education had shown a slight impact on the hemoglobin level status. The subjects with normal, mild hemoglobin level were increased a little and with severe and moderate hemoglobin level subjects were reduced after intervention in the experimental group rather than the before nutrition education. However, all the experimental subjects gained the knowledge towards the anemia status and their prevention methods. Their knowledge, attitude and practice scores were increased at $1 \%$ significant difference level after nutrition education intervention. The prevalence of anemia among girls can be reduced in the adolescent phase of life, through Nutrition education at community level and school based level programmes.

\section{Introduction}

The iron-deficiency anemia has remained the top cause of disability in India. Anemia is widespread with poverty, malnutrition, poor sanitation and imbalanced vegetarian diet. The frequent occurrences of malaria and worm infestations also result in a high incidence of anemia. WHO (2016) defines anemia as a condition in which the number and size of red blood cells, or the hemoglobin concentration, falls below an established cutoff value, consequently impairing the capacity of the blood to transport oxygen around the body. Anemia is an indicator of both poor nutrition and poor health.

Worldwide, the highest prevalence of irondeficiency anemia among women, including adolescents, is observed in India. Between 6070 per cent of Indian adolescent girls are anemic $($ Hemoglobin $(\mathrm{Hb})<12 \mathrm{~g} / \mathrm{dl})$.

In respect to escalating trends of anemia in the 
country, several intervention strategies were implemented for improving iron status of vulnerable groups globally. Intervention strategies for improving the iron status are basically grouped into two. These are the food-based strategies, which include fortification of foods with micronutrients and dietary diversification to increase production and consumption of foods rich in iron, vitamin $\mathrm{C}$ and folate. Supplementation with specific micronutrient for the vulnerable groups and public health measures to control diseases, especially malaria and worm infestations are the non-food based strategies (Gillespie, 1998; Vijayaraghavan, 1995). However the food based strategies need to concentrate on the challenges that have limited effectiveness, such as poor attendance at antenatal clinics, in sufficient doses for supplementation, or insufficient emphasis on behavioral aspects of using supplements on a regular basis (Lutter $e t$ al., 2011).

Health and Nutrition education have been defined as educational measures for inducing desirable behavioral changes for the ultimate improvement in the nutritional status of people. It is an inexpensive, highly efficacious health technology and services exist for many leading diseases in developing countries.

Nutrition education, which is practical and adopted to suit the socio - economic conditions, food habits and local food resources, can tackle the problem to a great extent. The health and nutrition education will provide individuals with enough information and motivation to make wise decisions about selections for good health. Hence, health and nutrition education to improve and ensure regular consumption of foods rich in iron, folate and vitamin $\mathrm{C}$ and to reduce consumption of interfering substances are also important for the prevention and control of anemia.

Adolescents are one of the most important groups of any society, but nutritionally vulnerable for iron deficiency because of the double demand of growth and activity. Nutrition education might be the important strategies to combat nutritional problems, particularly iron deficiency anemia in adolescent girls, by stressing the importance of haemopoitic nutrients and consumption of green leafy vegetables which are an excellent source of iron and micronutrients. The importance of nutrition education as a means for improving the nutrition and health of community has been increasingly realized during recent years. Adolescence is menarche onset period and lasts with growth and development and follows reproductive age. The adolescents, girls constitute a vulnerable group, particularly in developing countries where they traditionally marry at an early age and exposed to a greater risk of reproductive morbidity and mortality (Kaur S et al., 2006). Adolescence period is a time where 'before first pregnancy', 'during pregnancy' and 'after pregnancy' can occur in India. Hence the adolescence stage is the best moment in time for Health and nutrition education intervention to combat iron deficiency in women.

Several studies (Das et al., 1984; Seshadri et al., 1984; Jean Burley Moore, 2009) have suggested that supplementation with iron may increase hematological indicators of iron status. Some researchers (Kanani and Agarwal, 1997) have documented a significant relationship between nutrition knowledge and nutrition behavior, specific to iron. It is presumed that detailed guidance on such topics as food purchasing, food preparation and serving sizes (Walbeck, 1973), nutrient value of foods and balanced diets (Howie, 1983), the importance of green leafy vegetables and interfering substances in the prevention of anemia will provide individuals with enough information and motivation to make wise decisions about selections for good health especially iron status health.

In this context, the present study is intended 
and implemented to increase knowledge about and promoting positive attitudes and behavior change towards child feeding practices, specific to iron intake through nutrition education strategy.

\section{Materials and Methods}

The present one is a community-based nutrition education intervention study to improve the iron status of adolescent's girls.

\section{Selection of subjects}

A total of 300 adolescent girls aged 13-17 years, with the hemoglobin level below 12 $\mathrm{mg} / 100 \mathrm{ml}$ and attending the school regularly were chosen from four villages of Moinabad mandal, Rajendranagar district, Telangana state, India. Then the subjects were suitably categorized into control (150) and experimental group (150).

\section{Collection of data}

A schedule was developed and standardized for collecting the information. General information pertaining to the type of family, family size, educational status and occupation of parents, food habits, and meal pattern were collected from all 300 subjects.

\section{Assessment of nutritional status of selected group}

Selected groups are divided into control and experimental groups. The selected adolescent group was checked for clinical symptoms of nutrient deficiencies related to protein, iron, calcium, vitamin $\mathrm{C}, \mathrm{B}$ complex vitamins, energy, vitamin A, etc. The anthropometry measurements height and weight of all subjects were taken to assess their nutritional status using Body Mass Index (BMI). Dietary intake information was collected using 3-day recall method before after the intervention in the control and experimental groups.

\section{Intervention method}

Four months nutritional Educational programme was given to experimental group using appropriate audiovisual aids covering information on anemia its causes and symptoms, measures to be taken to prevent anemia, iron rich foods, good cooking practices and balanced diet, and health and sanitation etc.

\section{Assessment of KAP scores of selected group}

Standard questionnaire was developed and used to assess the knowledge, attitude and practice levels of both control and experimental groups before and after evaluation.

Pre and post assessment was done for the subjects to recognize the impact of nutrition education programme on improvement of the Knowledge, Attitude and Practice levels (KAP) of the selected subjects. The details on dietary habits, food and nutrient intake and hemoglobin levels were also carried out before and after nutrition education programme to analyze the impact of the nutrition education on the anemia status of adolescent girls.

\section{Results and Discussion}

\section{General information of the adolescents selected}

Majority of the subject's belonged to nuclear family $(63.3 \%)$ followed by the joint family $(35 \%)$ and then extended family (1.7\%). Most the subjects family income was between Rs.5000/- to 10,000/- (49\%) followed by 10,000 to $15,000(23 \%)$ and $<5000 /(21 \%)$ and minority $(7 \%)$ of the subjects had the family income with $>15,000$ per month. Most of the subject's family belongs to agriculture and 
their main occupation was agricultural related works. Majority of the subjects were $(94.7 \%)$ were non-vegetarians whereas $5 \%$ of the subjects were vegetarians and negligible $(0.3 \%)$ subjects were ova-lacto-vegetarians. The meal pattern of selected subjects indicated that the majority of the subjects $(53.3 \%)$ had the habit of taking three meals per day followed by two meals per day (29.7\%), four times per day $(7.1 \%)$ and minority $(1 \%)$ of the subjects had daily meal only once.

Occurrence of nutritional signs and symptoms

Figure 1 indicates the percentage of common nutritional signs and symptoms present among the subjects. Pale conjunctiva (57.3\%), lusterless hair (52\%) and dyspigmention (36.7) were the main problems found in selected adolescents. Mottled enamel, angular stomatitis, thinness, straightness, easy pluckable hair and cheilosis were also seen in the adolescents. The similar results were reported by Kaur (2011) that 68 per cent of the subjects depicted pallor skin. Respondents were more familiar with signs like pale palm and conjunctiva, all constituting 70 per cent of the signs enumerated.

\section{Anthropometric measurements}

Table 1 clearly indicates that the mean height of subjects in 13years age group subjects were $143.7 \mathrm{~cm}$, weight was $32.1 \mathrm{kgs}$ and mean BMI was 15.7, whereas in 14years age group subjects, the mean height was $147 \mathrm{~cm}$, mean weight was $36.3 \mathrm{kgs}$ and mean BMI was 16.6 , and in 15years age group subjects, the mean height, weight and BMI were $149 \mathrm{~cm}, 37.5 \mathrm{kgs}$, and 16.3, whereas in 16years age groups subjects, the height was $150 \mathrm{~cm}$, weight $36.7 \mathrm{kgs}$ and mean BMI was 16.2. And in 17 years age group the mean height, weight and were $151 \mathrm{~cm}, 45.5 \mathrm{kgs}$, and 19.9 respectively. The average mid-upper arm circumference
(MIUC) of the subjects was 21.63. The average weight, height, and BMI of the subjects were $35.48 \mathrm{~kg}, 147.4 \mathrm{~cm}$ and 16.29 $\mathrm{cm}$ respectively. Mean height, weight and $\mathrm{BMI}$ of all the adolescent girls were below the standard reference value (WHO, 2007).

The findings of Sachan et al., (2012) revealed that the mean height and weight of the subjects from urban as well as rural schools were below the expected measures for their age group. The Nutritional status of selected subjects categorized based on BMI classification, and it showed $86.4 \%$ of the subjects were underweight, $13.3 \%$ of the subjects were having normal BMI and $0.3 \%$ was overweight (Fig. 2).

\section{Knowledge, attitude, and practice scores of selected adolescents}

The nutrition education intervention brought a drastic change in the KAP scores of subjects. The subjects with high attitude levels were increased from $10.33 \%$ (31 no) to $90.67 \%$ (272 no), average attitude levels were reduced from 53\% (159 no) to $90.33 \%$ (272 no) whereas low attitude levels were reduced from $36.67 \%$ (110no) to no one. Accordingly, the knowledge levels from $9.33 \%$ (28no) to $41.33 \%$ (124 no), $72 \%$ (216 no) to $15.33 \%$ (46 no) and $18.67 \%$ (56 no) to nil was observed in high, average and low levels respectively. The KAP practice levels were increased from $7.67 \%$ (23 no) to $75.67 \%$ (227 no) in the high category, decreased from $74.33 \%$ (223no) to $21.67 \%$ (65no) in average level and $18 \%$ (54no) to 2.67 (8no) in lowest category. This demonstrates that the nutrition education had showed a good impact on knowledge, awareness and practice levels of selected subjects (Table 2).

The impact of nutrition education was assessed through mean difference of KAP scores and the details are represented in Table 
3. It clearly showed that there are $1 \%$ level significant differences in mean KAP scores before and after nutrition education intervention. The findings of the present study are also on par with the findings of Sharma and Chawla (2005), Meenakshi and Vyas (2003), Upadhyay et al., (2002), Sucharitha et al., (2007) and Kaur (2007) who observed highly significant gain in nutrition knowledge of school girls after imparting nutrition education. Thirty per cent gain in knowledge by comparing the scores of pre-test and posttest, as against to a high score $(>23)$ by the subjects in the post tests within the interval of seven days on the same questionnaire was indicated by Meenakshi and Vyas (2003). Upadhyay et al., was also reported that exposure to short lecture, and other visual aids such as folder, flash cards, posters and display of raw foods showed a significant rise in post exposure knowledge scores. Sucharitha et al., (2007) studied the impact of nutrition education through girl to girl approach at Hyderabad and reported that the consumption of micronutrient dense foods was found to be increased significantly after nutrition education intervention and the study proved that the girls were more participatory, active and efficient in sharing information. Nutrition education improved their mean nutrition knowledge scores significantly $(\mathrm{P}<0.01)$ from $11.17 \pm 1.42$ to $19.16 \pm 1.8$. The average contribution of carbohydrate, protein, fat, vitamin and minerals increased significantly after imparting nutrition education (Kaur, 2007).

\section{Impact of nutrition education intervention on food and nutrition intake}

The food intake of control and experimental group subjects was shown in Table 4. The intakes of all the foods were not adequate in both experimental and control groups. The nutrition education was given positive impact in food intake of subjects, especially with regard to leafy vegetables (28.4 g (control group), $32.2 \mathrm{~g}$ (experimental group), roots and tubers (32 g (control group), $58 \mathrm{~g}$ (experimental group), nuts and oilseeds (22 g (control group), $30 \mathrm{~g}$ (experimental group), and milk and milk products $50.7 \mathrm{~g}$ (control group), $61.2 \mathrm{~g}$ (experimental group). It has shown a $1 \%$ significance level in experimental group when compared with control group (Table 4).

Though it was not significant, nutrition education intervention brought a change in the intake other foods like pulses $(32.5 \mathrm{~g}$ (control group), $39.6 \mathrm{~g}$ (experimental group), fruits (46.25 g (control group), $57.5 \mathrm{~g}$ (experimental group), and fish and other seafood's (0.0 g (control group), $2.08 \mathrm{~g}$ (experimental group). Before nutrition education, the intake of fish and other seafood's were nil but increased to $2.08 \mathrm{~g}$ after the nutrition intervention programme.

The nutrition education intervention has come out with good results in the nutrient intake of the experimental group in different age groups compared with the control group and the results are presented in Table 5.

The intake of all the nutrients was higher in the experimental group compared with the control group of both 13-15 and 16-17 year age groups.

From the table 5, it clearly indicates that the intake of nutrients was lower in the control group, whereas it is $50 \%$ adequate in the experimental group except for calcium, iron, riboflavin, beta-carotene and retinol. This could be due to the increased intake of roots and tubers, leafy vegetables, nuts \& oilseeds, milk and milk products after the intervention programme (Table 4). 
Table.1 Anthropometric measurements of selected subjects according to age wise

\begin{tabular}{|l|l|l|c|c|c|c|c|}
\hline Age & $\begin{array}{c}\text { Mean } \\
\text { Height } \\
\mathbf{( c m})\end{array}$ & $\begin{array}{c}\text { Mean } \\
\text { weight }\end{array}$ & $\begin{array}{c}\text { Mean } \\
\text { (kg) }\end{array}$ & \multicolumn{3}{|c|}{ Nutritional status } & $\begin{array}{c}\text { Mean } \\
\text { BUI }\end{array}$ \\
\hline $\mathbf{1 3}$ & 143.7 & 32.1 & 15.7 & $8(8.7)$ & $0(0.0)$ & $84(91.3)$ & 20.8 \\
\hline $\mathbf{1 4}$ & 147.4 & 36.3 & 16.6 & $17(15.0)$ & $0(0.0)$ & $96(85.0)$ & 22.0 \\
\hline $\mathbf{1 5}$ & 149.4 & 37.5 & 16.3 & $6(9.0)$. & $1(1.5)$ & $60(89.5)$ & 21.0 \\
\hline $\mathbf{1 6}$ & 150.1 & 36.7 & 16.2 & $5(20.8)$ & $0(0.0)$ & $19(79.2)$ & 21.1 \\
\hline $\mathbf{1 7}$ & 151.5 & 45.5 & 19.9 & $4(100.0)$ & $0(0.0)$ & $0(0.0)$ & 24.3 \\
\hline All & 148.4 & 37.6 & 16.9 & $40(13.3)$ & $1(0.3)$ & $259(86.4)$ & 21.9 \\
\hline
\end{tabular}

Table.2 Pre and post KAP levels of selected subjects (control and experimental)

\begin{tabular}{|c|c|c|c|c|c|c|c|}
\hline \multirow[t]{2}{*}{ S. No. } & \multirow[t]{2}{*}{ Levels } & \multicolumn{3}{|c|}{ Pre intervention } & \multicolumn{3}{|c|}{ Post intervention } \\
\hline & & $\begin{array}{c}\text { High } \\
(8-10)\end{array}$ & $\begin{array}{c}\text { Average } \\
(5-7)\end{array}$ & $\begin{array}{l}\text { Low } \\
(0-4)\end{array}$ & $\begin{array}{l}\text { High } \\
(8-10)\end{array}$ & $\begin{array}{c}\text { Average } \\
(5-7)\end{array}$ & $\begin{array}{l}\text { Low } \\
(0-4)\end{array}$ \\
\hline 1. & Attitude & $\begin{array}{c}31 \\
(10.33)\end{array}$ & $\begin{array}{c}159 \\
(53.00)\end{array}$ & $\begin{array}{c}110 \\
(36.67)\end{array}$ & $\begin{array}{c}272 \\
(90.67)\end{array}$ & $\begin{array}{c}28 \\
(9.33)\end{array}$ & - \\
\hline 2. & Knowledge & $\begin{array}{c}28 \\
(9.33)\end{array}$ & $\begin{array}{c}216 \\
(72.00)\end{array}$ & $\begin{array}{c}56 \\
(18.67)\end{array}$ & $\begin{array}{c}124 \\
(41.33)\end{array}$ & $\begin{array}{c}46 \\
(15.33)\end{array}$ & - \\
\hline 3. & Practice & $\begin{array}{c}23 \\
(7.67)\end{array}$ & $\begin{array}{c}223 \\
(74.33)\end{array}$ & $\begin{array}{c}54 \\
(18)\end{array}$ & $\begin{array}{c}227 \\
(75.67)\end{array}$ & $\begin{array}{c}65 \\
(21.67)\end{array}$ & $\begin{array}{c}8 \\
(2.67)\end{array}$ \\
\hline
\end{tabular}

Table.3 The Impact of nutrition education on KAP levels

\begin{tabular}{c|l|c|c|c|c|c|c|} 
S. & \multirow{2}{*}{ Levels } & \multicolumn{2}{|c|}{ PRE } & \multicolumn{2}{c|}{ POST } & t value & p value \\
\cline { 3 - 8 } No. & & Mean & SD & Mean & SD & & \\
\hline 1. & Awareness & 4.1 & 1.8 & 7.7 & 0.79 & 31.72 & $0.0001 * *$ \\
\hline 2. & Knowledge & 4.8 & 1.4 & 7.4 & 0.85 & 26.93 & $0.0001 * *$ \\
\hline 3. & Practice & 4.8 & 1.3 & 7.7 & 1.27 & 27.63 & $0.0001 * *$ \\
\hline
\end{tabular}

Table.4 The mean food intake of the subjects before and after nutrition education intervention

\begin{tabular}{|c|c|c|c|c|c|c|}
\hline \multirow[t]{2}{*}{ FoodGroups } & \multicolumn{2}{|c|}{ Experimental-post } & \multicolumn{2}{|c|}{ Control-post } & \multirow[t]{2}{*}{ t value } & \multirow[t]{2}{*}{ pvalue } \\
\hline & Mean & SD & Mean & SD & & \\
\hline Cereals & 343.2353 & 32.28737 & 336.75 & 36.03 & 0.79 & 0.43 \\
\hline Pulses & 39.65714 & 32.89806 & 32.5 & 11.6 & 1.21 & 0.22 \\
\hline Leafy veg & 32.22857 & 21.14587 & 10 & 28.4 & 3.71 & $0.004 * *$ \\
\hline Roots \& tubers & 58 & 40.25277 & 32 & 25.26 & 3.236 & $0.0019 * *$ \\
\hline $\begin{array}{l}\text { Other } \\
\text { vegetables }\end{array}$ & 65.28571 & 55.65125 & 73.75 & 45.68 & 0.696 & 0.488 \\
\hline $\begin{array}{l}\text { Nuts and oil } \\
\text { seeds }\end{array}$ & 30.71429 & 14.88733 & 22 & 4.84 & 3.2933 & $0.0016^{* *}$ \\
\hline $\begin{array}{l}\text { Condiments } \\
\text { and spices }\end{array}$ & 16.65714 & 7.463982 & & & & 0.137 \\
\hline Fruits & 57.57143 & 59.64624 & 46.25 & 46.28 & 0.8872 & 0.3781 \\
\hline $\begin{array}{l}\text { Fishes and } \\
\text { other sea } \\
\text { foods }\end{array}$ & 2.083333 & 9.991316 & o & 0 & 1.243 & 0.2181 \\
\hline $\begin{array}{l}\text { Meat and } \\
\text { poultry }\end{array}$ & 15.85714 & 35.54646 & 20 & 40 & 0.4588 & 0.6478 \\
\hline $\begin{array}{l}\text { Milk and milk } \\
\text { product }\end{array}$ & 61.25 & 16.35075 & 50.71429 & 20.11 & 2.405 & $0.0189 * *$ \\
\hline Sugar & 14 & 5.43 & 12.25 & 6.01 & 1.27 & 0.205 \\
\hline
\end{tabular}


Table.5 Age wise nutrient intake and percent adequacy of selected subjects after intervention

\begin{tabular}{|c|c|c|c|c|c|c|c|c|c|c|c|c|}
\hline \multirow{3}{*}{ Nutrients } & \multicolumn{6}{|c|}{ Control -post } & \multicolumn{6}{|c|}{ Experimental -post } \\
\hline & \multicolumn{3}{|c|}{$13-15 y$} & \multicolumn{3}{|c|}{$16-17 y$} & \multicolumn{3}{|c|}{$13-15 y$} & \multicolumn{3}{|c|}{$16-17 y$} \\
\hline & $\begin{array}{c}\text { Mea } \\
\text { n } \\
\text { inta } \\
\text { ke }\end{array}$ & RDA & $\begin{array}{c}\text { Perce } \\
\text { nt } \\
\text { adequ } \\
\text { acy }\end{array}$ & $\begin{array}{c}\text { Mean } \\
\text { intak } \\
\text { e }\end{array}$ & $\begin{array}{c}\text { RD } \\
\mathbf{A}\end{array}$ & $\begin{array}{c}\text { Perc } \\
\text { ent } \\
\text { adeq } \\
\text { uacy }\end{array}$ & $\begin{array}{l}\text { Mean } \\
\text { intake }\end{array}$ & $\begin{array}{c}\text { RD } \\
\mathbf{A}\end{array}$ & $\begin{array}{c}\text { Perce } \\
\text { nt } \\
\text { adequ } \\
\text { acy }\end{array}$ & $\begin{array}{c}\text { Mea } \\
\text { n } \\
\text { inta } \\
\text { ke }\end{array}$ & $\begin{array}{c}\text { RD } \\
\mathbf{A}\end{array}$ & $\begin{array}{c}\text { Perce } \\
\text { nt } \\
\text { adequ } \\
\text { acy }\end{array}$ \\
\hline Protein & 41.2 & 51.9 & 79.4 & 40.98 & 55.5 & 73.8 & 45.5 & 51.9 & 87.7 & 43.3 & 55.5 & 77.9 \\
\hline Fat & 17.4 & 40 & 43.6 & 23.4 & 35 & 66.9 & 40.4 & 40 & 101 & 34.7 & 35 & 99.3 \\
\hline Energy & 1722 & 2330 & 73.9 & 1899 & 2440 & 77.8 & 1947 & 2330 & 83.5 & 1813 & 2440 & 74.3 \\
\hline Calcium & 325 & 800 & 40.6 & 365 & 800 & 45.6 & 482 & 800 & 60.2 & 283 & 800 & 35.4 \\
\hline Iron & 9.72 & 27 & 36.0 & 9.36 & 26 & 35.9 & 11.9 & 27 & 44.3 & 14.8 & 26 & 56.5 \\
\hline Zinc & 5.43 & 11 & 49.4 & 5.68 & 12 & 47.3 & 6.1 & 11 & 55.7 & 7.53 & 12 & 62.8 \\
\hline Vitamin C & 34.6 & 40 & 86.6 & 47.69 & 40 & 119 & 51.0 & 40 & 128 & 42.4 & 40 & 105.9 \\
\hline $\begin{array}{l}\text { Beta } \\
\text { carotene }\end{array}$ & 1960 & 4800 & 40.8 & 2994 & 4800 & 62.4 & 2797 & 4800 & 58.3 & 1742 & 4800 & 36.3 \\
\hline Retinol & 117 & 600 & 19.53 & 0.00 & 600 & 0.00 & 139.8 & 600 & 23.3 & 0.75 & 600 & 0.12 \\
\hline Thiamine & 0.62 & 1.2 & 52.2 & 0.57 & 1 & 57.4 & 0.742 & 1.2 & 61.9 & 0.75 & 1 & 75.2 \\
\hline Riboflavie & 0.66 & 1.4 & 47.5 & 0.59 & 1.2 & 49.3 & 0.95 & 1.4 & 67.8 & 0.53 & 1.2 & 44.5 \\
\hline Niacen & 10.1 & 14 & 71.8 & 10.9 & 14 & 72.7 & 11.00 & 14 & 78.6 & 12.3 & 14 & 87.4 \\
\hline $\begin{array}{l}\text { Dietary } \\
\text { folate }\end{array}$ & 123 & 150 & 81.9 & 101 & 200 & 50.7 & 139.5 & 150 & 93.0 & 139 & 200 & 69.3 \\
\hline
\end{tabular}

Table.6 The mean nutrient intake of the subjects before and after nutrition education intervention

\begin{tabular}{|c|c|c|c|c|c|c|}
\hline & \multicolumn{2}{|c|}{ EXPERLIENTAL-post } & \multicolumn{2}{|c|}{ CONTROL-post } & \multirow[t]{2}{*}{ txalue } & \multirow[t]{2}{*}{ pxalu } \\
\hline & Mean & SD & Mean & SD & & \\
\hline Carbohydrates(gms) & 345.78 & 34.62 & 327.75 & 32.33 & 2.251 & $0.02 *$ \\
\hline Protein(gm) & 45.29 & 8.81 & 43.37 & 7.37 & 0.988 & 0.326 \\
\hline Fat (gm) & 38.96 & 12.13 & 24.15 & 13.81 & 4.766 & $0.001 * *$ \\
\hline Total minerals (gm) & 6.902 & 1.37 & 6.411 & 1.09 & 1.659 & 0.101 \\
\hline Crude fibre (gm) & 5.15 & 1.87 & 11.67 & 42.9 & 0.893 & 0.372 \\
\hline Energy (kcal) & 1933.5 & 216.51 & 1794.60 & 180.15 & 2.917 & $0.0048^{* *}$ \\
\hline Calcium(mg) & 463.24 & 203.48 & 354.97 & 84.9 & 2.905 & $0.0049 * *$ \\
\hline Iron(mg) & 12.28 & 4.003 & 10.37 & 2.49 & 2.3969 & $0.019 *$ \\
\hline Zinc (mg) & 6.29 & 0.80 & 5.62 & 0.60 & 3.963 & $0.002 * *$ \\
\hline Vitamin C (mg) & 51.49 & 26.81 & 43.0 & 16.22 & 1.602 & 0.113 \\
\hline Beta-carotene ( $\mu \mathrm{g})$ & 2660.119 & 1287.38 & 2445.35 & 1344.8 & 0.682 & 0.497 \\
\hline Rationol ( $\mu \mathrm{g})$ & 120.04 & 239.97 & 129.73 & 251.94 & 0.164 & 0.86 \\
\hline Thiamine (mg & 0.75 & 0.19 & 0.69 & 0.16 & 1.429 & 0.15 \\
\hline Riboflavin (mg) & 0.9 & 0.5 & 0.702 & 0.30 & 2.008 & $0.048 *$ \\
\hline Niacin (mg) & 11.43 & 2.52 & 10.37 & 2.30 & 1.838 & 0.07 \\
\hline Folic acid ( $\mu \mathrm{g})$ & 137.542 & 57.67 & 145.42 & 61.71 & 0.551 & 0.582 \\
\hline
\end{tabular}




\section{Schematic Representation of the Study}

Screening of subjects based on hemoglobin level

Categorization (Control and experimental groups with 150 members in each)

Collection of baseline information<smiles>[AlH]</smiles>

Assessment of nutritional status

(Anthropometry, clinical signs and symptoms \& Dietary information)

Pre assessment of KAP levels

$\downarrow$

Nutrition education (Experimental group only)

Post assessment of KAP levels \& Nutritional status

(Dietary information and hemoglobin levels)

Fig.1 Type of clinical signs and symptoms present in selected subjects

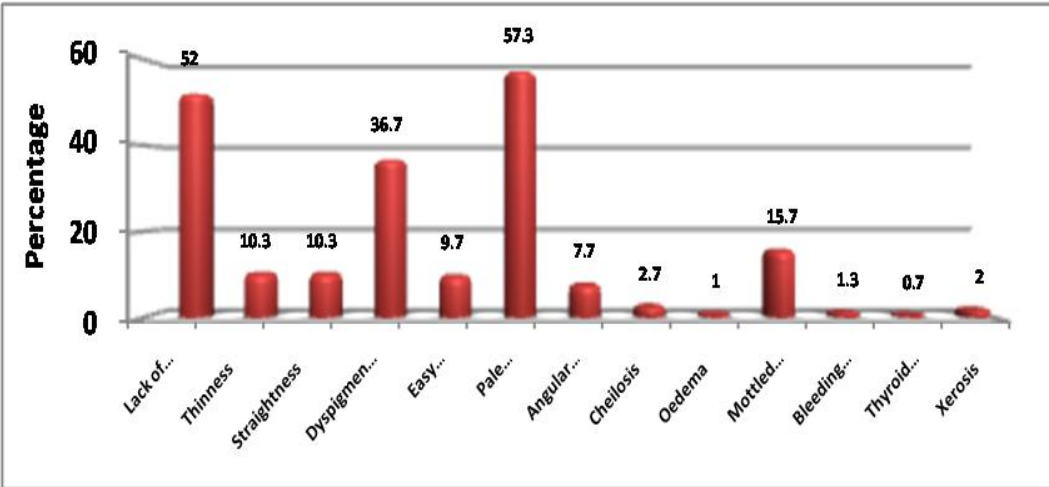

Fig.2 Age wise nutritional status of selected subjects

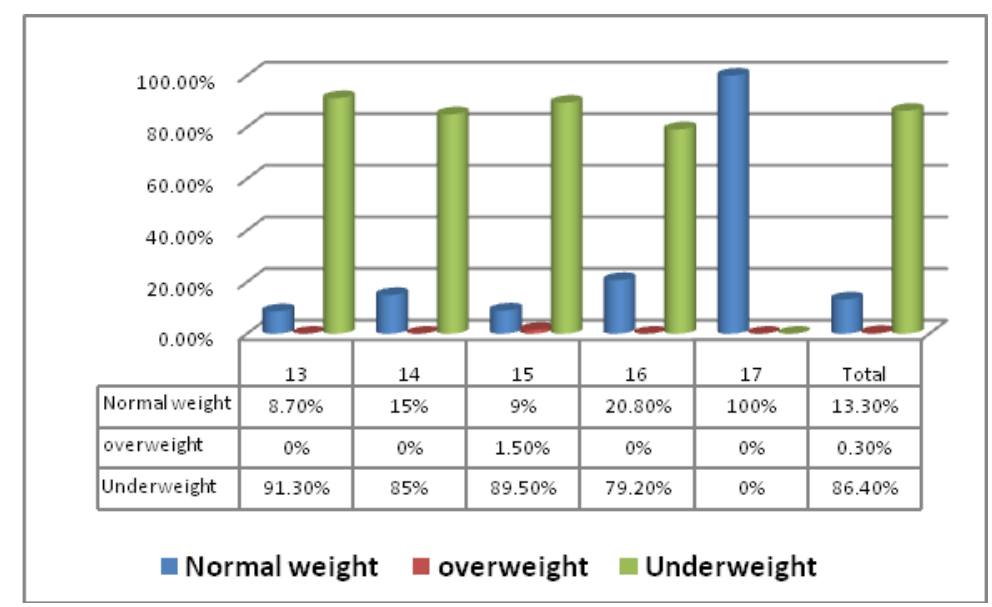


Fig.3 Impact of intervention on hemoglobin levels of selected subjects

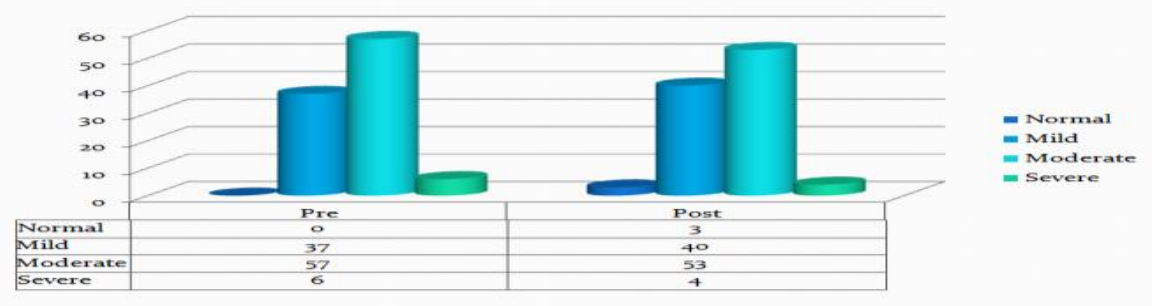

The Similar observation has been reported by Sujata and Kousalya (2016), Tarvinder Jeet Kaur et al., (2007). There was a decrease in the mean intake of most of the foods in the control group from pre to post-intervention period. But in the experimental group except for milk intake, the intake of all the foods was found to be slightly increased from pre to post. However, statistically, no significant difference was found in the intake of foods from pre to postintervention period in both the groups. But the association between IEC and mean intake of foods from pre to post as indicated by " $r$ " value in both groups.

\section{Impact on nutrient intake of the subjects before and after nutrition education intervention}

The nutrient intake of selected subjects showed positive impact through nutrition education. The table 6 showed that, the nutrients fat, energy, calcium, iron and riboflavin intake was significantly $(\mathrm{p}<0.001)$ higher in experimental group when compared with the control group.

A similar finding on the nutrient intake of the adolescent girls has been reported by Aazam doust Mohammad et al., (2000). The post intervention nutrient intake except for the intake of thiamine, fat, vitamin $\mathrm{C}$, calcium, iron and folic acid continued to be below the RDA in both the groups. However, the intake of energy and protein was found to be adequate in addition to calcium, vitamin $\mathrm{C}$ and thiamine in the experimental group. The results indicated that the lack of attitude, knowledge and practice on dietary habits and health has definitely had a negative effect on their nutrient intake. Though it was not significant, IEC intervention was found to bring about positive changes in the dietary intake of nutrients.

\section{Impact of nutrition education intervention on Hemoglobin level}

Nutrition education had shown a slight impact on hemoglobin levels. From the Figure 3, it is observed that only the subjects with normal, mild hemoglobin level were changed to increase after intervention rather than the before nutrition education.

The subjects with severe and moderate hemoglobin levels were reduced after nutrition education intervention. Nevertheless, all the experimental subjects gained the knowledge towards the anemia status and their prevention methods (Table 2). Malhotra and Passi (2004) studied the hemoglobin status of adolescent girls in rural blocks of Delhi, Rajasthan and Uttar Pradesh, and reported that the incidence of mild, moderate and severe anemia was found to be 50 per cent, 44.4 per cent and 2.8 per cent respectively and only 2.8 per cent of the subjects had normal hemoglobin levels. Similarly, the prevalence of anemia in the present study showed a similar trend to that of the present study.

The prevalence of moderate and mild anemia among adolescent girls based on the data of 16 districts of the country was 50.9 and 32.1 per cent respectively as per the survey conducted by ICMR, 2001). In the present study, the prevalence of moderate and mild anaemia 
among the subjects was found to be 57 and 37 per cent respectively. 5-7 per cent higher prevalence in mild and moderate anemia category was observed in the present study as compared to the data given by ICMR (2001). The strategies to combat iron deficiency anemia have been in operation for over two decades, there has been no perceptible biological impact on the prevalence of iron deficiency anaemia. Among the constraints, the most important are; lack of coordination, lack of proper orientation and training to the functionaries, poor monitoring and supervision and absence of health and nutrition education (Vijayaraghavan, 1990).

From the study it is found that rural adolescent girls are lack of basic information on health, food and nutrition. It is may be due to poor purchasing capacity, poor access to nutritious food, false beliefs and taboo, lack mass media like $\mathrm{TV}$, radio and newspaper which provides information good nutrition and government and non-government programmes available for health and well-being of adolescents. In the present study health and nutrition education intervention had a significant impact on nutrition knowledge, awareness and practice levels among subjects. Hence it can be concluded that nutrition education plays a vital role in improving the nutritional knowledge, which in turn will improve the nutritional status of the respondents. However, health and nutrition education intervention will not bring the instant changes in nutritional and hemoglobin level status. The dietary diversification through nutrition education on a long term basis may possibly reduce the risk of anemia. It can be possible by inclusion of Health and nutrition education progrmme along with school education programmes and other nutritional programmes planned by the government and non-government agencies. Furthermore, continued health and nutrition education will definitely have a positive effect on the health, nutritional status adolescents who are going to future mothers and who are responsible for the health of their family members.

\section{References}

Aazam Doustmohammadian1, Seyed Ali Keshavarz, Sorayya Doustmohammadian, Eelizabeth, B. M., 2000. Developmental psychology: a life span approach, 5th Edn Tata McGraw Hill

Das BK, Bal MS, Tripathi AM, Singla PN, Agarwal DK, Agarwal KN.1984. Evaluation of frequency and dose of iron and other hematinics - an alternative strategy for anemia prophylaxis in rural preschoolers. Indian Pediatr; 21: 933-938. E27.

Gillespie S.1998. Major Issues in the Control of Iron Deficiency. The micronutrient Initiative and UNICEF.

Howie SM.1983. Nutrition education for children under 12 years in North Staffordshire. Hum Nutr Appl Nutr 37A: 54-58.

ICMR, 2001, Micronutrient deficiency disorders in 16 districts of India. Part- I Report of an ICMR Task force study District Nutrition Project, New Delhi. 30 India. Proceedings of National Symposium on child health and nutrition. Maharaja Sayajirao University, Baroda: 29-35.

Jean BurleyMoore, Lisa Pawloski,Claudia Rodriguez, Laura Lumbi, and Rita Ailinger 2009, The Effect of a Nutrition Education Program on the Nutritional Knowledge, Hemoglobin Levels, and Nutritional Status of Nicaraguan Adolescent Girls Public Health Nursing Vol. 26 No. 2, pp. 144-152 0737-1209/

Kanani S, Agarwal V. 1997. Reducing anemia and improving growth in early adolescence: Nutrition education alone can make a difference. Paper presented at the $16^{\text {th }}$ International Congress of Nutrition, Montreal, Canada. July 27 Aug 1.

Kaur S. and Deshmukh PR., Garg B.S., 2006. Epidemiological correlates of nutritional anemia in adolescent girls of rural Wardha. Indian J Community Med. 31(4): 255- 258. 
Kaur S., 2011. A Comparison of Nutritional Profile and Prevalence of Anemia among Rural Girls and Boys. Journal of Exercise Science and Physiotherapy. Vol.7 (1): 1118.

Kaur, T.J., Kochar, G.K. and Agarwal, T. 2007. Impact of nutrition education on nutrient adequacy of adolescent girls. Stud. Home Commu. Sci., 1 (1): 51-55.

Lutter CK, Daelmans BM, de Onis M, Kothari MT, Ruel MT, Arimond M, 2011. Undernutrition, poor feeding practices, and low coverage of key nutrition interventions. Pediatrics. 128: E1418-

Malhotra, A. and Passi, S.J., 2004. Incidence of iron deficiency anaemia among adolescent girls in rural blocks of North

Meenakshi, M. and Vyas, 2003, Nutritional knowledge to adolescent girls. IX Asian congress of Nutrition: 237.

Sachan B., Idris M.Z., Jain S., Kumari R. and Singh A., 2012. Nutritional Status of School Going Adolescent Girls in Lucknow District. J Med Nutr. Nutraceut. Pediatrics. Vol. 31(1): 101-5.

Seshadri S, Hirode K, Naik P, Malhotra S., 1984. An effective intervention to reduce the prevalence of anemia in children. Indian J Med Res 80: 164-173.

Sharma, Sonica and Parmjit K. Chowla. 2005. Impact of nutritional counseling on anthropometric and biochemical parameters of school girls (7-9) years. Anthropologist, 7(2):121-125.

Sucharitha, k.v., Suneetha, E., Krishnapriya, A., 2007, Nutrition education through girl to girl approach. Paper presented at the 39th National Conference, Hyderabad, 15-17 November, p. 59. Sujatha K. and Kowsalya S. Socio economic and dietary assessment of anaemic adolescent girls (13-18yrs) in rural Coimbatore.. Int. $j$. adv. res. 4(11): 1628-1633 (2016).

Tarvinder Jeet Kaur, G.K. Kochar and Taru Agarwal, 2007. Impact of Nutrition Education on Nutrient Adequacy of Adolescent Girls, Stud, Home Comm. Sci., 1(1): 51-55

Upadhyay, S., Kumar, A.R., Raghuvanshi, R.S. and Singh, B.B., 2002. Impact of Nutrition Education on knowledge and haemoglobin status of Hill women of India, Proceedings of Workshop on Research Methodologies for Micronutrient Research: 9-13.

Vijayaraghavan K, Brahman GNV, Nair KM, Akbar D, Rao NP.1990. Evaluation of National Nutritional Anaemia Prophylaxis Programme. Indian J Pediatr 57: 183-190.

Vijayaraghavan K.1995. Strategies for control of micronutrient malnutrition: Indian $\mathbf{J}$ Med Res Nov; 102: 216-22.

Walbeck NH.1973. Percepts, paragons and practice: the effects of various methods of nutrition instruction on attitudes, knowledge and behaviour. J Soc Psych 91: 197-205.

WHO, 2007. IDD and their control and global progress in their elimination. Assessment of iron deficiency disorders and monitoring their elimination, Edn. 3, Geneva: World Health Organization. 614.

WHO, 2016. International Institute for population sciences, Deemed University, Mumbai.http://www.who.int/maternal_ch ild_adolescent/topics/adolescence/dev/ne/ 2016

\section{How to cite this article:}

Kamalaja, T., M. Prashanthi and Rajeswari, K. 2018. Effectiveness of Health and Nutritional Education Intervention to Combat Anemia Problem among Adolescent Girls. Int.J.Curr.Microbiol.App.Sci. 7(09): 3152-3162. doi: https://doi.org/10.20546/ijcmas.2018.709.393 